\title{
$\mathrm{Ni}-\mathrm{TiO}_{2}$ 共析とその共析機構
}

\author{
山口文 雄*, 小浦 延 幸**
}

\section{Studies on the Co-deposition Mechanism of $\mathrm{Ni}-\mathrm{TiO}_{2}$}

Fumio YAMAGUCHI* and Nobuyuki KOURA**

\begin{abstract}
The co-deposition mechanism of $\mathrm{TiO}_{2}$ and $\mathrm{Ni}$ was studied. The amount of $\mathrm{TiO}_{2}$ particles in composite coating films increased linearly with the electrodeposition time and amount of Nickel deposited. Therefore, it was surmised that $\mathrm{TiO}_{2}$ particles close to the cathode are entrapped by the reduction of $\mathrm{Ni}^{2+}$ ion to $\mathrm{Ni}$.

$\mathrm{TiO}_{2}$ particles that adsorb cationic surfactants have a positive charge. Therefore, this adsorption affects the concentrarion of $\mathrm{TiO}_{2}$ particles close to the cathode and then the amount of co-deposited $\mathrm{TiO}_{2}$.
\end{abstract}

Key Words : Co-deposition Mechanism, $\mathrm{Ni}_{-}-\mathrm{TiO}_{2}$, Electrodeposition

\section{1. 緒言}

粒子を分散しためっき液中で，電気めっきあるいは化 学めっきを行うと，粒子を包含する複合めっき膜が得ら れることはよく知られている。

その粒子の共析機構については, Guglielmi ${ }^{1)}$ の共 析機構が通説になっている。即ち (1) 被覆率は大きいが 弱い吸着力の物理的吸着, (2) カソード電場によるクー ロン力の強い吸着の 2 段階過程による共析機構が考えら れているが，はっきりとした結論は得られていない。そ れは, 複合めっきには関与する因子が多く, まとめきれ ないことによるあのと考える。その解決策として, めっ き液の液組成を単純化して研究する方法む行われつつあ るが2), 本研究では, 通常のめっき液組成における複 合めっきについて, 共析に関与する因子と粒子の共析量 から共析機構の検討を行った。

なお, 分散粒子には, 前報 ${ }^{3)}$ のフッ化グラファイト とは異なり，界面活性剤の吸着が無くてあ分散が可能な 二酸化チタン（以下 $\mathrm{TiO}_{2}$ と記す）を選び, 共析量の評 価は, 従来の重量\%, 体積\%で表わす共析率ではなく, 共析の実態がつかみやすい粒子の共析重量で行った。そ の結果，いままでの共析率評価では見えなかった現象を とらえることができた。

\section{2. 試料および実験方法}

\section{1 分散粒子}

分散粒子は，平均粒径 $0.330 \mu \mathrm{m}$ （㑣島津製作所製 遠

* 大阪職業能力開発短期大学校（二596-01 大阪府岸和田市稲 葉町 1778)

Osaka Polytechnic College (1778, Inaba-cho, Kishiwadashi, Osaka 596-01)

** 東京理科大学 理工学部（干278 千葉県野田市山畸 2641） Fac. of Sci. \& Tech., Tokyo Univ. of Sci. (2641, Yamazaki, Noda-shi, Chiba 278)
心沈降式粒度分布装置 SA-CP 4 Lによる実測値）のア ナターゼタイプ $\mathrm{TiO}_{2}$ 粒子を用いた。

なお，表面電位の測定のための粒子には，測定機器の 関係加ら平均粒径 $0.441 \mu \mathrm{m}$ （上記機器による実測値） の $\mathrm{TiO}_{2}$ 粒子（㑣）アメタリック製 純度 $99.99 \%$ アナター ゼタイプ）を用いた。

\section{2 カチオン界面活性剤および複合めっき夜}

$\mathrm{TiO}_{2}$ 粒子表面に正の電位を付与するため使用する力 チオン界面活性剂は, めっき膜に包含されるとめっき膜 の物性に良い影響を与えないことから, 少量の添加で 酸性電解液中でもその効果の期待できる前報と同様のフ ルオロカーボン系カチオン界面活性剤 $\left[\mathrm{C}_{8} \mathrm{~F}_{17} \mathrm{SO}_{2} \mathrm{NH}\right.$ $\left.\left(\mathrm{C}_{2} \mathrm{H}_{5}\right)_{2} \mathrm{R}\right)^{+} \mathrm{I}^{-}$(住友スリーエム侏製) を選んだ。なお, $\mathrm{TiO}_{2}$ 粒子への正電位の付与は, $\mathrm{TiO}_{2}$ 粒子 $1 \mathrm{~g}$ あたり 10 , 25, $50 \mathrm{mg}$ のカチオン界面活性剂が溶解している水溶液 中に, $\mathrm{TiO}_{2}$ 粒子を添加して, $\mathrm{TiO}_{2}$ 粒子にカチオン界面 活性剂を吸着させる方法で行った。

電解液は, ニッケルワット浴 $\left(\mathrm{NiSO}_{4} \cdot 6 \mathrm{H}_{2} \mathrm{O}: 240\right.$ $\left.\mathrm{g} / \mathrm{L}, \mathrm{NiCl}_{2} \cdot 6 \mathrm{H}_{2} \mathrm{O}: 45 \mathrm{~g} / \mathrm{L}, \mathrm{H}_{3} \mathrm{BO}_{3}: 30 \mathrm{~g} / \mathrm{L}\right)$ に $\mathrm{TiO}_{2}$ 粒子 $10 \mathrm{~g} / \mathrm{L}$ を分散した液, およびそれに界面活性 剂を添加した液を複合めっき液とした。

\section{3 電解方法および共析粒子量の測定}

複合めっきは, 粒子を分散した液温 $45^{\circ} \mathrm{C}$ の複合めっ き液中で各種電流密度, 時間で電解を行い, 直径 $8 \mathrm{~mm}$ のステンレス棒の側面 $10 \mathrm{~cm}^{2}$ に $\mathrm{Ni}^{-T i O} 2$ 複合めっき膜 を得た。その膜中の共析 $\mathrm{TiO}_{2}$ 粒子量は, ステンレス棒 よりはく離した複合めっき膜を $1: 1$ の硝酸液中で溶解 し，その溶液をデシヶーター中で保存乾燥した孔径 0.2 $\mu \mathrm{m}$ のメンブランフィルターで吸引ろ過して, フィルター 上に残った $\mathrm{TiO}_{2}$ 粒子を, デシケーター中で乾燥し, 重 量測定を行い共析量とした。

なおフィルターを通過する共析粒子については, 前報 と同様にプラス補正を行い, 共析量とした。 


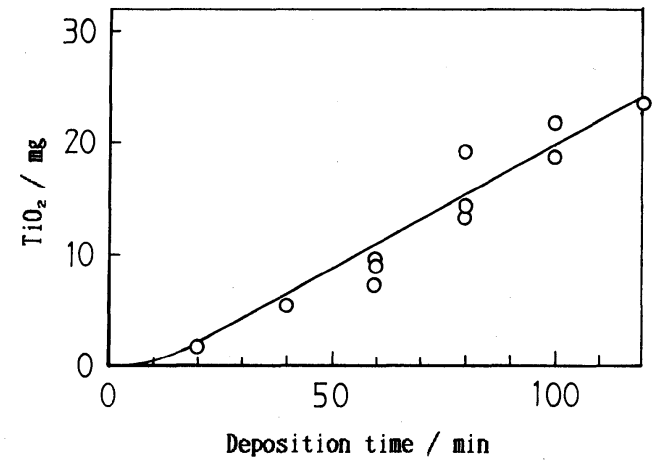

Fig. 1 Amount of co-deposited $\mathrm{TiO}_{2}$ with electrodeposition time.

Current density : $40 \mathrm{~mA} \cdot \mathrm{cm}^{-2}$

Electrolyte temperature : $45^{\circ} \mathrm{C}$

\section{4 粒子の表面電位の測定}

粉体や繊維の表面電位の測定に利用されている流動電 位法により, $\mathrm{TiO}_{2}$ 粒子の表面電位の測定を行った。流 動電位は，流動電位測定装置 ZP-10B（侏島津製作所製） により測定し，(1) 式からゼー夕（ $\zeta ）$ 電位を求めた。

$$
\zeta=(4 \pi \eta / \varepsilon) \times(\lambda \mathrm{E} / \mathrm{P})
$$

ここで， $\mathrm{E}$ は流動電位， $\mathrm{P}$ は液体を流すために加えた圧 力, $\eta$ は液体の粘性係数, $\lambda$ は液体の導電率, $\varepsilon$ は液体 の誘電率である。

\section{3．実験結果および考察}

\section{1 電解時間およひ $\mathrm{Ni}$ 析出量と粒子の共析量}

電解時間と $\mathrm{TiO}_{2}$ 粒子の共析量の関係を図 1 に示す。 20 分以後の共析量は, 電解時間にほぼ比例して直線的 に増加する。

一方, 図 2 から粒子の共析量は, Ni 析出量の増加に と屯なって増加していることがわかる。このことから， 粒子の共析は, Ni の析出時に取り込まれる機構で, 共

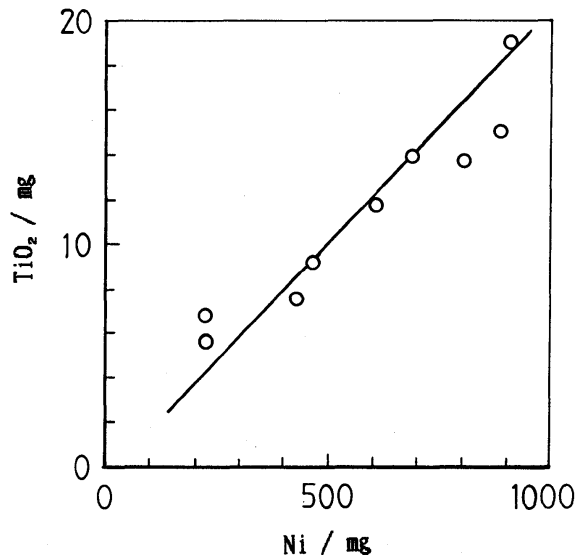

Fig. 2 Relation between an amount of deposited $\mathrm{Ni}$ and a co-deposited $\mathrm{TiO}_{2}$ particle.

析することが考えられる。すなわち，陰極付近の粒子が, 析出過電圧により引き込まれ，あるいはクーロン力で陰 極に吸着され $\left.{ }^{4} ， 5\right)$ その粒子の周りに Ni の析出が進む ことにより, $\mathrm{TiO}_{2}$ 粒子が埋め込まれるかたちで共析す るあのと考えられる。

\section{2 電流密度およひ電解時間と共析量}

$\mathrm{TiO}_{2}$ 粒子分散濃度 $10 \mathrm{~g} / \mathrm{L}$, 通電量 1440 クーロン一定 とし, 電流密度を変動させて, 粒子の共析量 (図 1 とは, 条件が同一でないので比較できない）をみると，図 3 に 示すように, 電流密度が増加するにともなって, 粒子の 共析量は減少傾向を示し（図 $3 \mathrm{a}$ ), 電解時間の増加に とあなって，粒子の共析量は増加傾向を示している（図 $3 \mathrm{~b}$ )。なお，電流密度による共析量の減少は，前報の フッ化グラファイト共析の場合之同様, 過電圧の変化で 説明づけられよう。

\section{3. $3 \mathrm{TiO}_{2}$ 粒子の表面電位}

親水性の $\mathrm{TiO}_{2}$ 粒子は，純水中で $+4.95 \mathrm{mV}(\mathrm{pH} 5.60)$
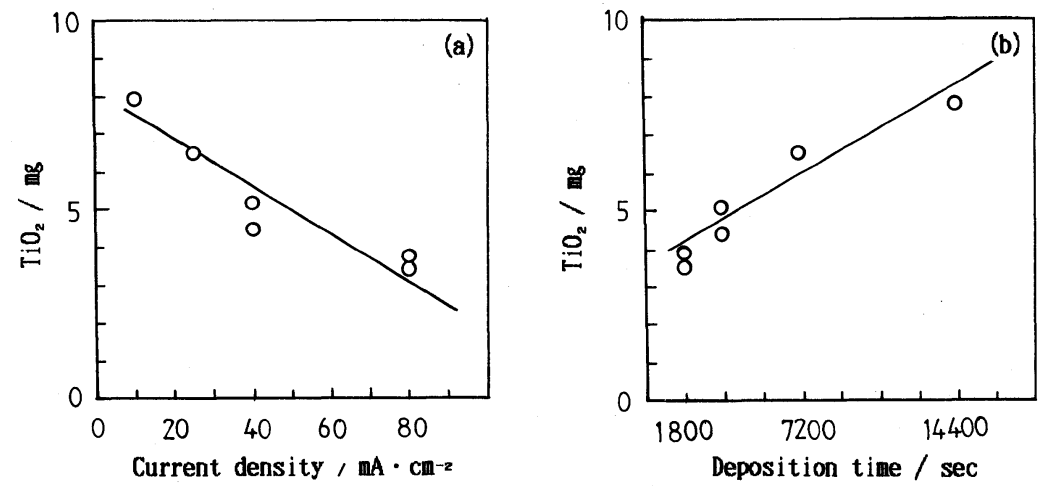

Fig. 3 Amount of co-deposited $\mathrm{TiO}_{2}$ with current density and electrodeposition time. Electricity : 1440 coulomb 


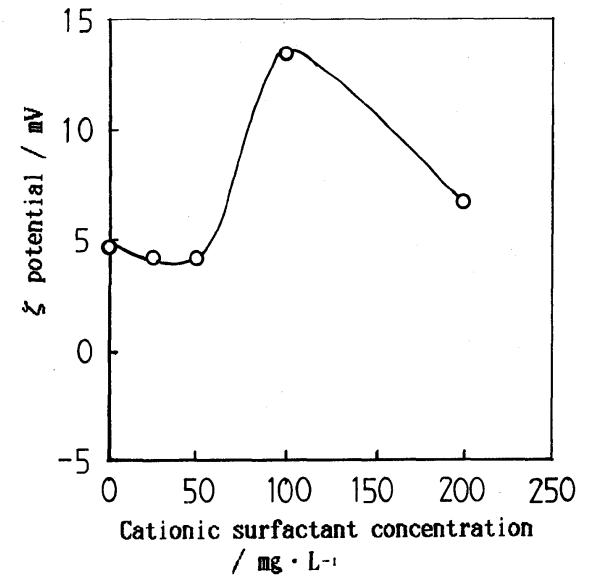

Fig. 4 Relation between amount of adsorbed cationic surfactant on $\mathrm{TiO}_{2}$ and $\zeta$ potential.

の正の表面電位を示す。この系に, カチオン界面活性剂 を添加すると, 活性剤分子は親水基を粒子側に, 疎水基 を外側に向けて吸着するため, 粒子の表面電位は減少し （図 4)，粒子は撥水性を帯びるようになる。さらに，界 面活性剂を添加していくと, 正の電荷をもつ活性阂の親 水基を外側に向けての吸着が生じるため粒子の表面電位 は+13.43mV（pH 5.67）（図 4）にまで高まる。しかし， この $+13.43 \mathrm{mV}$ の表面電位をむつ粒子あ硫酸ニッケル 溶液 $\left(\mathrm{NiSO}_{4} \cdot 6 \mathrm{H}_{2} \mathrm{O} 240 \mathrm{~g} / \mathrm{L}\right)$ の添加量の増加にと あない, 対イオンを吸着するため電気二重層の拡散層が 圧縮され，表面電位は減少する（図 5 )。この傾向は, 粒子の表面電位に関係なく同様であるが，正の表面電位 の大きいほうが顕著に現れている。

\section{3. $4 \mathrm{TiO}_{2}$ 粒子の表面電位と共析量}

$\mathrm{TiO}_{2}$ 粒子分散濃度 $10 \mathrm{~g} / \mathrm{L}$, 電解時間 60 分の電解条件 で, カチオン界面活性剤吸着 $\mathrm{TiO}_{2}$ 粒子と吸着させてい ない $\mathrm{TiO}_{2}$ 粒子の粒子共析量を比較した（図 6 )。どの 電流密度においても, カチオン界面活性剂吸着 $\mathrm{TiO}_{2}$ 粒 子の共析量が多く, その差は, 電流密度の大きいほど顕 著であった。これは前報の電流密度の増加からくる析出 過電圧の増加, および粒子の正の表面電位の大きさによ るあのと考えられる。

以上のことから, 陰極近傍の $\mathrm{TiO}_{2}$ 粒子は, $\mathrm{Ni}^{2+} 1$ オンの還元反応により取り込まれるかたちで共析するあ のと考えられ, その粒子の共析量は, 陰極近傍の粒子濃 度に影響されることが分かった。

\section{4. 結言}

$\mathrm{Ni}-\mathrm{TiO}_{2}$ 複合めっき膜中の $\mathrm{TiO}_{2}$ 粒子の共析量から $\mathrm{TiO}_{2}$ 粒子の共析機構の検討を行い, 以下のことが明ら かになった。

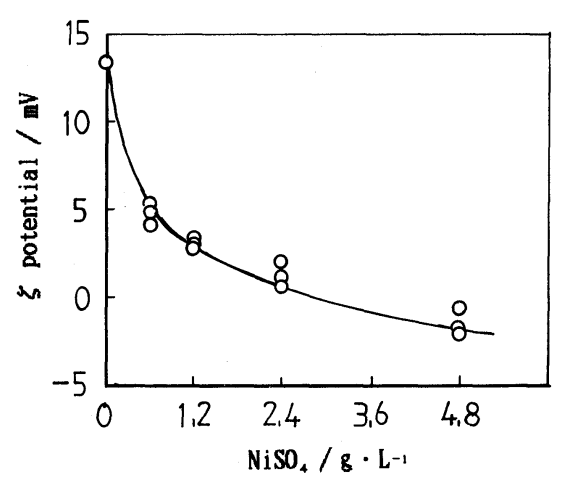

Fig. 5 Relation between concentration of $\mathrm{NiSO}_{4}$ and $\zeta$ potential of $\mathrm{TiO}_{2}$.

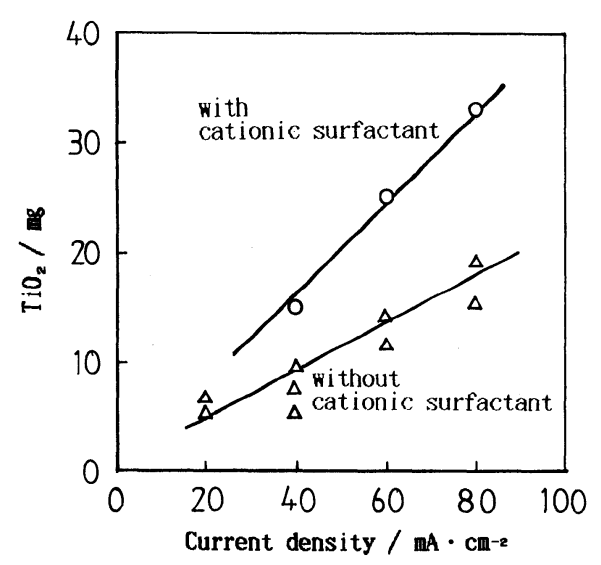

Fig. 6 Change of co-deposited $\mathrm{TiO}_{2}$ amount with the current density.

Electrolyte: Watt's type Nickel bath added $10 \mathrm{~g} \cdot \mathrm{L}^{-1}$

$\mathrm{TiO}_{2}$ particle with $(\bigcirc)$ or without $(\triangle)$ cationic surfactant

（1）粒子の共析量は陰極近傍の粒子濃度に比例すること が分かる。

(2) Ni の析出過電圧は, 陰極近傍の粒子濃度に関係し, 粒子の共析量に関与している。

(3) $\mathrm{TiO}_{2}$ 粒子は, カチオン界面活性剤を吸着することに より正電位を有することができ, 析出過電圧の影響とあ いまって陰極近傍の粒子濃度に大きく影響している。

(Received October 13, 1995 ; Accepted November 22, 1995)

\section{文献}

1) N. Guglielmi ; J. Electrochem. Soc., 119, 1009 (1972)

2）林 秀考; 表面物性研究会テキスト（表面技術協会関西支 部), 5 月, 15-24 (1992)

3 ）山口文雄, 小浦延幸; 表面技術, 47，448（1996）

4) F. K. Sauter ; J. Electrochem. Soc., 110, 557 (1963)

5) F. K. Sauter ; Metal, 18, 596 (1964) 